$42: 42$

$<$ 症例報告 $>$

肉腫様変化を伴った肝細胞癌の 2 剖検例

中正 恵二* 山口 桂 山元 哲雄
安室 芳樹 東野 - 彌**

要 旨：肉腫様細胞 (SC) 成分を伴う肝細胞癌 (HCC) の 2 剖検例を各種指標で用いた免疫組 織化学的染色結果を加えて病理組織学的に検討した。 2 症例とも HCC 成分と SC 成分間に移 行像を伴うとともに症例 1 では両成分にマロリー体の出現を認めた. 免疫組織化学的染色結果 では, 症例 1 の両成分に $\alpha$-フェトプロテインの発現を, 症例 2 では両成分の一部にCEA の発 現を認めた。さらに 2 症例ともに両腫瘍成分は胆管細胞としての CK 発現像を示した. 以上の 結果をもとに SC 成分を伴う HCC の組織起源について文献的考察を加えて報告する.

索引用語：肝細胞癌 肉腫様細胞肝動脈塞栓療法 Cytokeratin

\section{はじめに}

肝細胞癌 ( $\mathrm{HCC})$ には肉腫样細胞 (SC) を伴う症例 が稀に存在し，このSC成分出現の要因の一つとして HCC 局所への積極的抗癌療法の関与が指摘されてい $ろ^{1 \sim 4}$. しかし, 無治療例にも肉腫様変化を認める例が 存在し ${ }^{3.4}$, その組織学的起源が注目される.今回, 著 者らは 2 例の肉腫様細胞（SC）を伴う HCC を経験し たので各種指標を用いた免疫組織化学的染色を施行 し，とくにCytokeratin (CK) 発現像に着目して，そ の組織起源について検討した。

\section{症 例 1}

症例：74歳, 女性.

既往歴・家族歴：特記すべきことなし。

飲酒歴・輸血歴：なし.

現病歴および現症の経過：1984年より肝機能障害の ため本学内科にて通院加療を受けていた。1989年 4 月 の腹部超音波検查にて $88 / 5$ K径約 $1 \mathrm{~cm}$ の結節性病変 を指摘され，HCCの診断のもと肝動脈塞栓療法 (TAE) 目的で入院となり，6月に右肝動脈 (RHA) より最初のリピオドール.TAE(Lp.TAE)が行われた。 以後 3 年 6 力月の間に再発が確認されるごとに計 4 回 の Lp-TAE(Lp : 2 6ml, ファルモルビシン: 10〜20 $\mathrm{mg}, \mathrm{GS}$ powder) が施行された。1992年 6 月最終の Lp-TAE 終了後, 経過観察されていたが, 同年12月胸 部X-Pにて胸水貯留を認めたため加療目的で入院す
るも肝不全状態が進行し，1993年 2 月16日死亡した。 血液検查成績：最終入院時の結果を Table 1 に示 した.

剖検所見：剖検は死後 1 時間 30 分で行った。腹水は 約 $250 \mathrm{~m} l$ で黄色透明であった. 肝重量は $1,000 \mathrm{~g}$ で表面 は顆粒状の山凸を示し, 割面では幅の狭い線維結合織 で境された偽小葉をびまん性に諗める乙型肝硬変像を 呈した．主病巣として肝右葉前区域招よび後区域にわ

Table 1 Laboratory data on last admission.

\begin{tabular}{|c|c|c|c|c|}
\hline WBC & & $24 \times 10^{2} / \mu l$ & T.Bil & $0.66 \mathrm{mg} / \mathrm{d} l$ \\
\hline $\mathrm{RBC}$ & & $271 \times 10^{4} / \mu l$ & GOT & $40 \mathrm{KU}$ \\
\hline $\mathrm{Hb}$ & & $7.7 \mathrm{~g} / \mathrm{d} l$ & GPT & $7 \mathrm{KU}$ \\
\hline $\mathrm{Ht}$ & & $24.3 \%$ & LDH & $596 \mathrm{WU}$ \\
\hline PLT & & $4.2 \times 10^{4} / \mu l$ & ALP & 3.3 BLU \\
\hline PT & & $76 \%$ & LAP & 127 GRU \\
\hline Fib & & $198 \mathrm{mg} / \mathrm{d} l$ & $\gamma$ GTP & $24 \mathrm{mIU} / \mathrm{d} l$ \\
\hline T.P & & $7.15 \mathrm{~g} / \mathrm{d} l$ & $Z T T$ & $24.5 \mathrm{U}$ \\
\hline ALB & & $3.65 \mathrm{~g} / \mathrm{d} l$ & TTT & $11.2 \mathrm{U}$ \\
\hline PF. & $\mathrm{AL}$ & $53.5 \%$ & TG & $64 \mathrm{mg} / \mathrm{d} l$ \\
\hline & $\alpha_{1}$ & $3.2 \%$ & T.Cho & $183 \mathrm{mg} / \mathrm{d} l$ \\
\hline & $\alpha_{2}$ & $7.5 \%$ & BUN & $16.6 \mathrm{mg} / \mathrm{d} l$ \\
\hline & $\beta$ & $10.4 \%$ & CRE & $1.04 \mathrm{mg} / \mathrm{d} l$ \\
\hline & $\gamma$ & $25.6 \%$ & & \\
\hline \multicolumn{5}{|c|}{ AFP $: 792 \mathrm{ng} / \mathrm{m} l$, PIVKA-II $: 1.02 \mathrm{AU} / \mathrm{m} l$} \\
\hline \multicolumn{5}{|c|}{$\mathrm{HCV} \mathrm{C100-3Ab(+)}$} \\
\hline
\end{tabular}

Keiji NaKasho*, Kei Yamaguchi, Tetsuo Yamamoto, Yoshiki Amuro and Kazuya Higashino** "兵庫医科大学病理学第 2 教室, “*同 内科学第 3 教室 $<$ 受付日1995年 7 月26日 $>$ 


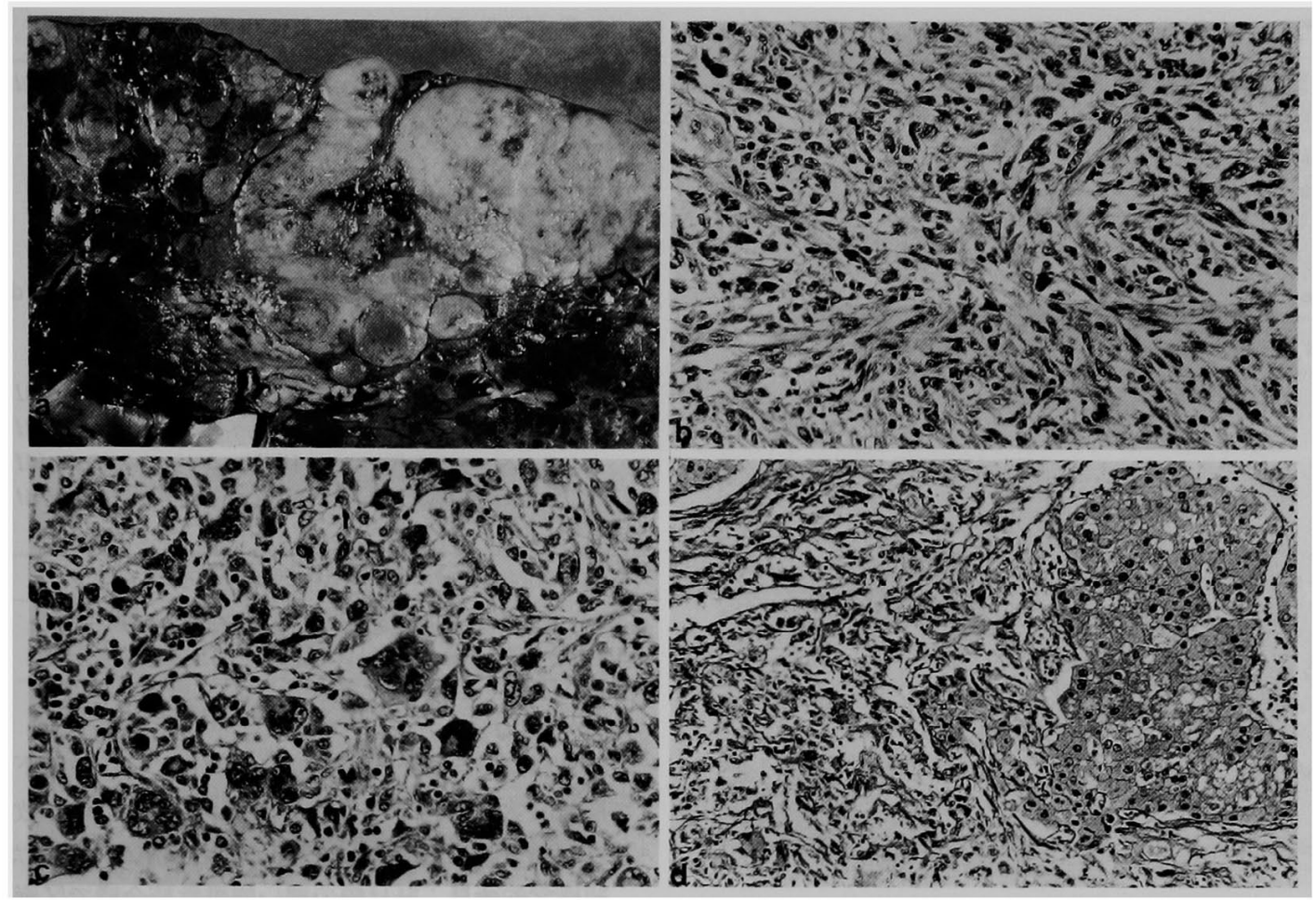

Fig. 1 (a) Gross appearance of hepatic tumor of posterior segment of the liver showing nodular growth with tumor emboli in the intrahepatic portal vein. (b) Specimen showing spindle-shaped sarcomatous cells (Hematoxylin eosin staining, $\times 190$ ). (c) Specimen showing sarcomatous appearance of free-cell type with prominent pleomorphism (Hematoxylin eosin staining, $\times 190$ ). (d) A transitional form from trabecular hepatocellular carcinoma to spindle-shaped cell sarcomatous lesion (Reticulin silver impregnation, $\times 190$ ).

たり $8.0 \times 5.5 \times 7.0 \mathrm{~cm}$ 大の黄白色調の多結節痹合状 結節を認め，他区域にも散在性に2cm大までの結節を 認めた(Fig. 1a)。また，右肝静脈内および右門脈枝に 腫湯塞栓を認めた。門脈圧元進を反映して食道下部の 静脈瘤および脾腫 $(200 \mathrm{~g})$ をみた。転移病巣としては, 肝門部枋よひ腹部大動脈周囲リンパ節に著明な転移を 認めた。

組織学的所見：肝は薄い線維性隔壁で境された偽小 葉結節をびまん性に形成する乙型肝硬変像を呈した。 肝右葉に見られた多結節癒合状腫瘍には，索状增殖を 示す中分化型 HCC 成分をみるとともに紡鍾形細胞の 疎な束状増殖，あるいは多核巨細胞を含み核異型が強 く遊離性に増殖する SC 成分を諗め(Fig. 1b, 1c), 両 成分間には移行像も見られた (Fig. 1d)。HCC 成分の 一部および遊離性 SC 部の一部にはマロリー体(MBs) も認められた(Fig. 2).また, 腫瘍の発育先端では SC 成分の類洞内浸潤性增殖が顕著であった。他区域にみ
られた小結節も同様に両成分の混在した組織像を呈し た.なお，リンパ節転移巣は主として SC 成分で占めら れていた。

\section{症 例 2}

症例: 68歳, 女性。

既往歴：1979年, ルポイド肝炎. 1981年, 左大腿骨 骨頭壊死に対して人工骨頭置換徳.

家族歴：姝：ルポイド肝炎.

飲酒歴：なし。

輸血歴：1981年, 人工骨頭置換術時.

現病歴および現症の経過：1979年に本学内科にてル ポイド肝炎の診断のもとプレドニン (Prd) 漸隇療法が 施行され, 以後 Prd 維持療法が継続された. 1992年 7 月の腹部超音波検查て $\mathrm{S} 6$ に径約 $2 \mathrm{~cm}$ 大の腫瘍性病変 を指摘され, HCC の診断のもと 8 月に RHA より Lp- 


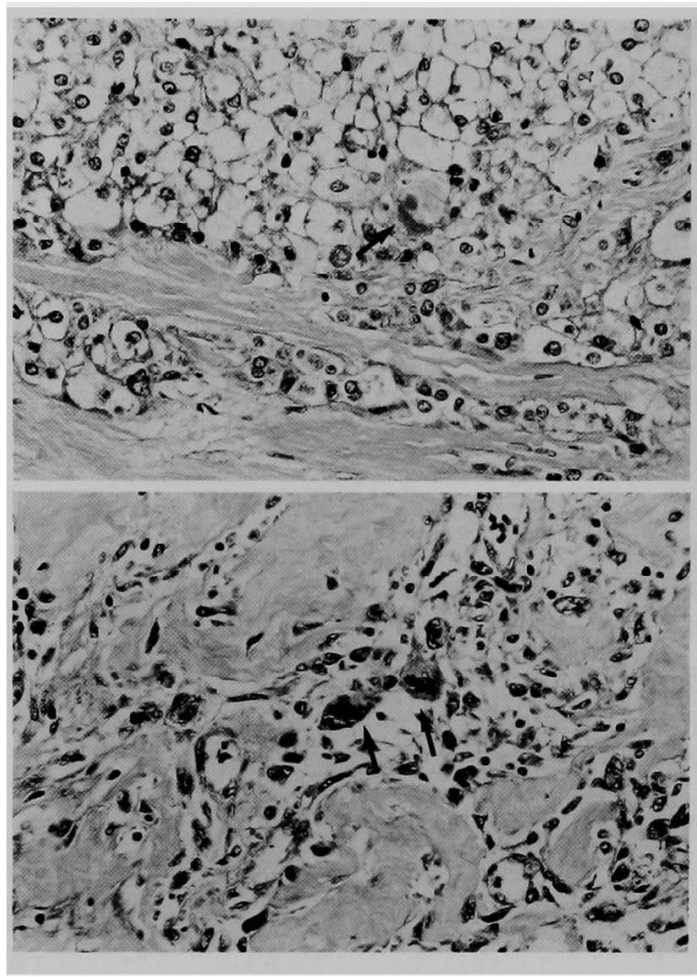

Fig. 2 (Top) specimen showing trabecular hepatocellular carcinoma with Mallory body formation (arrow) (Hematoxylin cosin staining, $x$ 380). (Bottom) Specimen showing free-cell type sarcomatous cells with Mallory body formation (arrow) (Hematoxylin eosin staining, $\times 380$ ).

$\mathrm{TAE}(\mathrm{Lp}: 3 \mathrm{~m} l$, アドリアマイシン : 20mg, GS powder）が施行されたが，1993年11月の腹部超音波で S5, S6, S7およびS8に再発が認められたため1994年 2 月 に再度 RHA より Lp-TAE (Lp: $3 \mathrm{~m} l$, ファルモルピ シン : $20 \mathrm{mg}, \mathrm{GS}$ powder)が実施された。同年 5 月上 り腰背部痛が出現增強するため精査加療を目的に入院 するも肝不全状態が進行し，6月12日に死亡した。

血液検查成績：最終入院時の成績を Table 2 に示 した.

剖検所見：剖検は死後 1 時間 30 分で行った．皮虚お よび眼球結膜の中等度黄染をみ，腹腔内に血性腹水を 約 $2,000 \mathrm{~m} l$ 認めた。肝重量は630g で, 表面は凹凸不整 の顆粒状を呈し, 割面では幅の狭い線維性間質で区画 された偽小集をびまん性にみる乙型肝硬変像を示し た. 腫瘍病巣として後区域に $5.0 \times 4.0 \times 6.0 \mathrm{~cm}$ 大の黄 白色調の結節型腫湯を認め(Fig. 3a), 他区域にも散在 性に小結節が存在した。また，肝静脈枝扔よび末梢門
Table 2 Laboratory data on last admission.

\begin{tabular}{|c|c|c|c|c|}
\hline WBC & & $48 \times 10^{2} / \mu l$ & $\mathrm{~T} \cdot \mathrm{Bil}$ & $2.0 \mathrm{mg} / \mathrm{d} l$ \\
\hline $\mathrm{RBC}$ & & $337 \times 10^{4} / \mu l$ & GOT & $66 \mathrm{KU}$ \\
\hline $\mathrm{Hb}$ & & $10.7 \mathrm{~g} / \mathrm{d} l$ & GPT & $48 \mathrm{KU}$ \\
\hline $\mathrm{Ht}$ & & $34.2 \%$ & LDH & $456 \mathrm{WU}$ \\
\hline PLT & & $6.3 \times 10^{4} / \mu l$ & ALP & $6.3 \mathrm{BLU}$ \\
\hline PT & & $72 \%$ & LAP & 697 GRU \\
\hline Fib & & $162 \mathrm{mg} / \mathrm{d} l$ & $y$-GTP & $553 \mathrm{mIU} / \mathrm{d} l$ \\
\hline T.P & & $5.0 \mathrm{~g} / \mathrm{d} l$ & ZTT & $9.2 \mathrm{U}$ \\
\hline Alb & & $2.79 \mathrm{~g} / \mathrm{d} l$ & TTT & $1.6 \mathrm{U}$ \\
\hline PF. & $\mathrm{AL}$ & $55.9 \%$ & TG & $113 \mathrm{mg} / \mathrm{d} l$ \\
\hline & $\alpha_{1}$ & $3.0 \%$ & T-Cho & $127 \mathrm{mg} / \mathrm{d} l$ \\
\hline & $\alpha_{2}$ & $9.6 \%$ & BUN & $24.9 \mathrm{mg} / \mathrm{d} l$ \\
\hline & $\beta$ & $10.9 \%$ & CRE & $1.09 \mathrm{mg} / \mathrm{d} l$ \\
\hline & $\gamma$ & $20.8 \%$ & & \\
\hline \multicolumn{5}{|c|}{ AFP $: 19.4 \mathrm{ng} / \mathrm{m} l$, PIVKA-II $<0.06 \mathrm{AU} / \mathrm{m} l$} \\
\hline \multicolumn{5}{|c|}{$\begin{array}{l}\operatorname{HCV} 2 \mathrm{Ab}(+), \operatorname{Cl} 100-3 \mathrm{Ab}(+), \mathrm{HCV} \cdot \mathrm{RNA}(+) \\
\operatorname{HBsAg}(-), \operatorname{HBsAb}(-), \operatorname{HBeAg}(-), \operatorname{HBeAb}(-)\end{array}$} \\
\hline
\end{tabular}

脈枝に腫瘍塞栓を認めた。転移に関しては，左肺下葉 に径 $2 \mathrm{~cm}$ 大で黄白色調の結節をみ，腹腔内には多数播 種性病巣を認めたが、リンパ節の腫大は認めなかった。

組織学的所見：肝は幅の狭い線維性結合織で区画さ れた偽小葉をみる乙型肝硬変像を示した，後区域に認 めた黄白色調の結節型腫場には広範囲に凝固壊死巣を みるが，大部分は核異型の強い紡鏵形細胞の蹯な束状 あるいは遊離性増殖を示す $\mathrm{SC}$ 成分よりなり，一部に 明調性の胞体を有し核の大小不同を伴い索状增殖を示 す中等度分化型の $\mathrm{HCC}$ 成分を認め，両成分の間には 移行像を伴っていた(Fig. 3b，3c).また腫瘍の発育先 端では SC 成分の類洞内浸潤性增殖が顕著であり, 散 在性に見られた小結節では SC 成分より構成されてい た。遠隔転移巣および播種性病䉓は SC 成分の增殖よ り構成され HCC 成分は認められなかった。

免疫組織化学的検討：2 例の腫煬組織について間接 免疫抗体法により $\alpha$-fetoprotein (AFP)，carcinoembryonic antigen (CEA), CA19-9, epithelial membrane antigen (EMA), vimentin (VMT), および cytokeratin-no. 7, -no. 8, -no. 18, -no. 19 (CK7, 8，18，19）の染色を行った，CKに関しては，2症例 ともに HCC および SC の両成分に CK7，8，18および 19が発現し (Fig. 4, Fig. 5), EMA およびVMTに 関しては, 症例 1 では両成分ともに陰性であったが, 症例 2 では両成分の一部に発現した(Fig. 6). AFPは 症例 1 の HCC 部および SC の一部に弱陽性ではある がその発現が認められ，また，CEA は症例 2 の両成分 

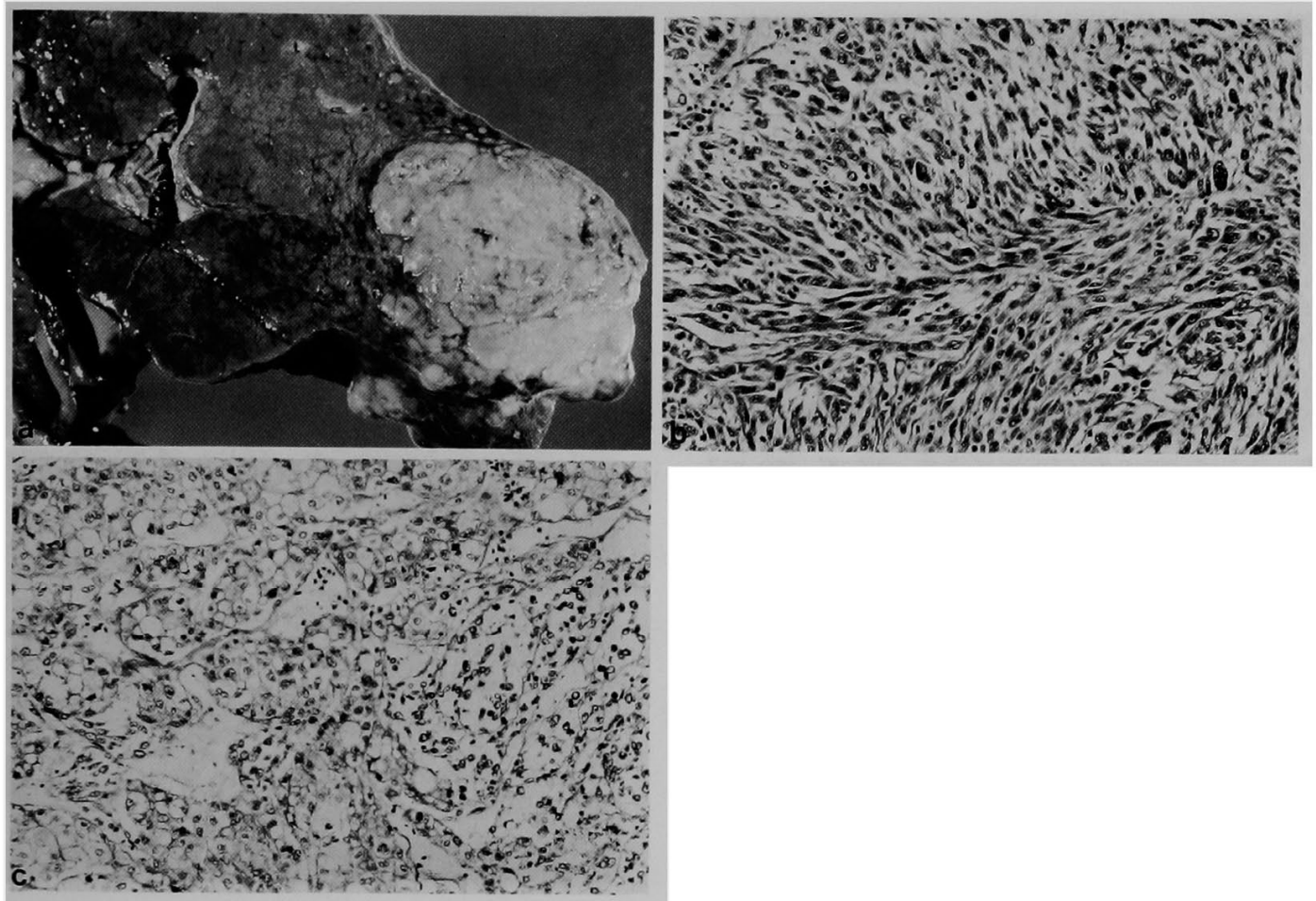

Fig. 3 (a) Gross appearance of hepatic tumor of posterior segment of the liver showing nodular growth with tumor emboli in the intrahepatic portal vein. (b) Specimen showing spindle-shaped sarcomatous cells (Hematoxylin eosin staining. $\times 190$ ). (c) A transitional form from trabecular hepatocellular carcinoma to sarcomatous lesion with appearance of free-cell type (Hematoxylin eosin staining, $\times 190$ ).

Table 3 Summary of immunohistochemical characteristics of Case 1 and Case 2.

\begin{tabular}{c|c|c|c|c|c|c|c|c|c|c}
\hline \multicolumn{2}{c|}{} & AFP & CEA & CA19-9 & EMA & VMT & CK7 & CK8 & CK18 & CK19 \\
\hline \multirow{3}{*}{ HCC } & Case 1 & $+/-$ & - & - & - & - & + & + & + & + \\
\cline { 2 - 12 } & Case 2 & - & $+/-$ & - & $+/-$ & $+/-$ & + & + & + & + \\
\hline \multirow{3}{*}{ SC } & Case 1 & $+/-$ & - & - & - & - & + & + & + & + \\
\cline { 2 - 11 } & Case 2 & - & $+/-$ & - & $+/-$ & $+/-$ & + & + & + & + \\
\hline
\end{tabular}

HCC : component of hepatocellular carcinoma.

$\mathrm{SC}$ : component of sarcomatous tumor.

EMA : epithelial membrane antigen, VMT : vimentin, CK7, 8, 18 \& 19 : cytokeratin-no. 7, -no.

8, -no. 18 \& -no. 19.

$(-)$ : None of tumor cells stained positively.

$(+/-)$ : A small number of turnor cells stained positively.

$(+)$ : Most of tumor cells stained positively.

の一部に発現していた(Fig，7)、CA19-9は 2 症例の両 成分とも陰性であった．2例の免疫組織化学的染色結 果の要点を Table 3 に示した。
考 察

肝腫瘍に HCC と SC の両成分を認めた場合，原発 性肝肉腫の偶然の併存による collision tumor である のか, HCC 成分の SC 変化であるのかの鑑別が必要と 
$46: 46$

肝

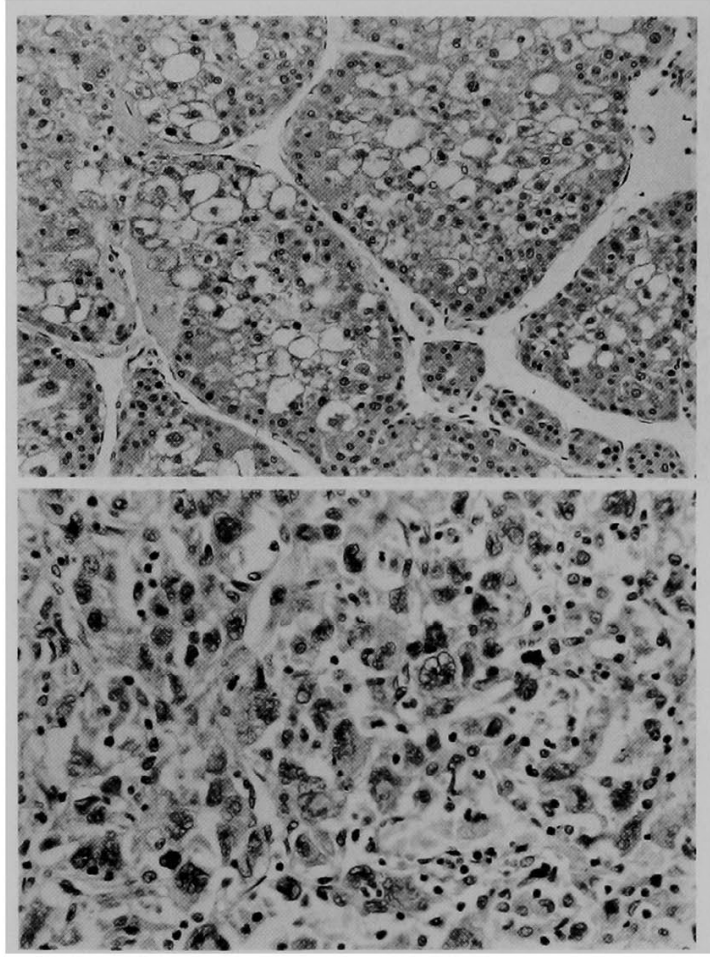

Fig. 4 Immunohistochemical staining for cytokeratin-no. 19 of Case 1.

(Top) Hepatocellular carcinoma components are positively stained $(\times 380)$. (Bottom) Sarcomatous cell components with pleomorphism are positively stained $(\times 380)$.

なる. 杉原 ${ }^{1} ら は \mathrm{HCC}$ の SC 変化の診断に有用な組織 所見として, HCC 成分より SC 成分への移行像を指摘 したが, 最近では, HCC の SC 変化と原発性肝肉腫と の鑑別に各種指標を用いた免疫組織化学的染色法の有 用性が報告されている2 の結果より SC 成分は上皮細胞由来で，何らかの要因 による HCC 成分の脱分化により誘導される形態変化 と考えられている. SC 成分を有する HCC は近年増加 する傾向にあり，その多くが TAE, one shot 動注等の 積極的抗癌療法を施行されており,HCC 成分の脱分化 に伴う形態変化の要因の一つとして積極的抗癌療法の 関与が推測されている3!

しかし, SC 成分を伴う HCC が全例過去に積極的抗 癌療法を受けているとは限らず，末治療例にもその出 現が認められ ${ }^{1-4)}, \mathrm{SC}$ 成分の発生に関わる他の要因も 考慮する必要がある。本 2 報告例も抗癌剤を含む Lp$\mathrm{TAE}$ が施行されており，SC成分增殖の誘因として積
37巻 1 号（1996）

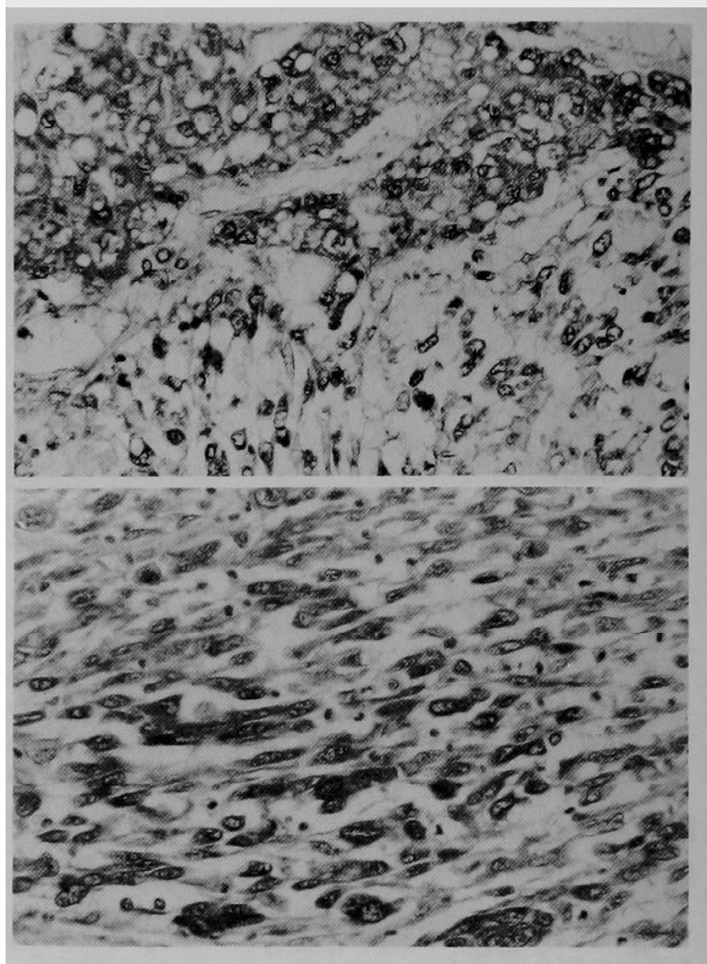

Fig. 5 Immunohistochemical staining for cytokeratin-no. 19 of Case 2.

(Top) Hepatocellular carcinoma components are positively stained $(\times 380)$. (Bottom) Spindleshaped sarcomatous cell components are positively stained $(\times 380)$.

極的抗癌療法の影響が, また，両例ともに HCC と SC 成分間に移行像を伴った点および SC 成分に上皮細胞 形質の発現を認めた点を考慮すれば，両症例の SC 成 分は上皮細胞成分に由来したと考えられる.HCC 成分 以外の組織成分を有する原発性肝癌の組織発生を考え る場合, 多方向性分化能を有する未熟肝上皮細胞の関 与の有無を検討すべきと考えるが，これまて組織発生 上からの検討はあまり成されていない。そこで，著者 らは, 特に CK 発現像に着目し, SC 成分を伴う HCC の組織起源について検討を試みた。CK は中間径フィ ラメント (IMF) を構成する蛋白成分で, IMF は異な る CK 蛋白の組み合わせにより構成され，各上皮細胞 特有の CK 発現像を示す。この特性を利用して, 腫愓 細胞あるいは培養上皮細胞の組織起源の特定が試みら れ，腫瘍性，非腫瘍性にかかわらず肝細胞は CK8およ び18を,胆管細胞ではこれらに加え CK7扔よび19を発 現するとされている5). 本報告の 2 症例はいずれも 


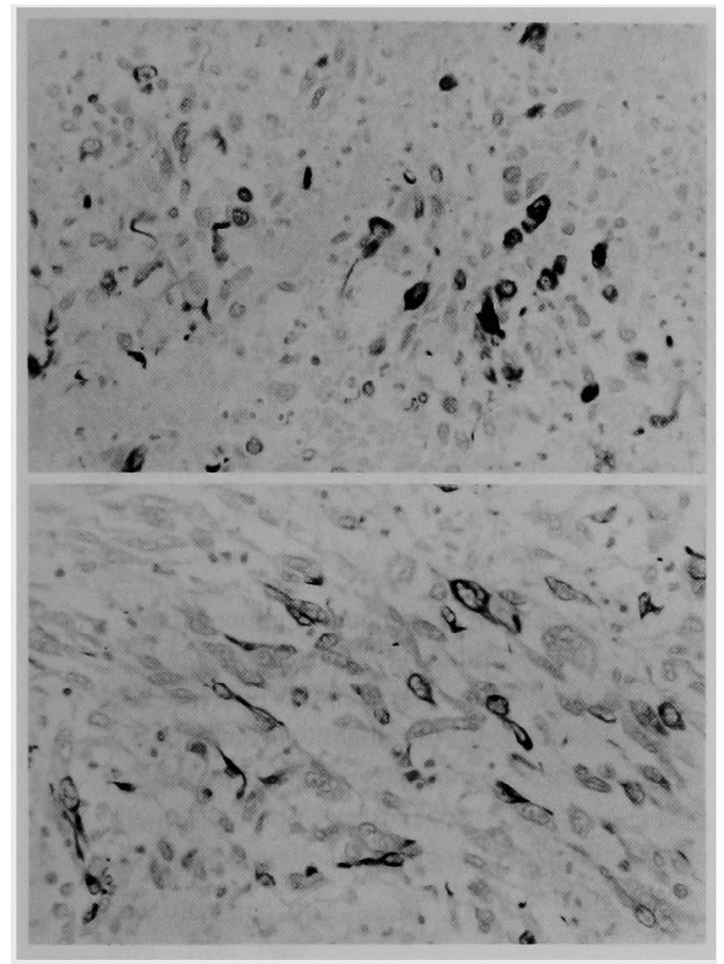

Fig. 6 (Top) Immunohistochemical staining for epithelial membrane antigen of Case 2. A few sarcomatous cells are positively stained $(\times 380)$. (Bottom) Immunohistochemical staining for vimentin of Case 2. A few sarcomatous cells are positively stained $(\times 380)$.

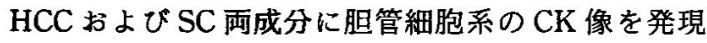
し, 症例 1 では両成分に MBs 出現および弱陽性なが ら AFP の発現を, また, 症例 2 では SC 成分に CEA 発現を伴っていた。このCK 発現像から 2 症例の両成 分は, いずれも単一の上皮細胞成分に由来することが 示唆され，かつこの上皮細胞成分は胆管細胞系と関連 し, 肝細胞および胆管細胞の両特性を発現し得る未熟 肝上皮細胞である可能性が示唆された.HCC 発生過程 に関与する特定の練胞として, ラット肝では化学発癌 過程の早期に門脈域周囲に一過性に出現する oval cell が知られている. 本細胞系は胆管細胞の CK 像を 発現するとともに肝細胞の特徴である AFP,アルブミ ン (ALB) 等を発現し，肝細胞および胆管細胞の両形 質を併わせ持ち，潜在的に肝細胞あるいは胆管細胞へ の移行能を有するのみならず HCC, 胆管細胞癌 (CCC)あるいは末分化癌発生への関与も指摘され, 多 方向性分化能の保有が示唆されている ${ }^{6 \sim 8)}$. Tsao ら
は, 成熟ラット肝由来の胆管細胞特性を有する株化培 養肝上皮細胞の化学発癌実験において肝芽腫, HCC, $\mathrm{CCC}$ の発生を認めたことから朋癌発生に関与する末 熟肝上皮細胞の存在を推測している。他方，七ト肝て は, 胎生20週未満の門脈域周囲の ductal plate の肝芽 細胞が肝細胞特性である AFP およびALB を発現し, かつ胆管細胞としての CK 像を示し, 肝細胞ないしは 胆管細胞に分化・成熟することが知られている ${ }^{10}$. ま た, 乳幼時期に好発し多彩な組織像を呈する肝芽腫は, 種々の分化・成熟段階の腫場性肝芽細胞を主体に構成 されるが，一部に腺管形成性腫湯，間葉系腫瘍，ある いは成人型 HCC 成分の併存ないしは移行等を伴うこ とが知られている。この併存する間葉系要素も未熟肝 上皮細胞に起源するとされ, 本腫湯の発生母細胞とし て胎生期の多方向性分化能を有する未熟肝上皮細胞が 想定されている ${ }^{11,12)}$. 肝芽腫の組織像の多様性につい ては, 胎生期の発癌の時期, あるいは発癌する細胞の 成熟度に依存すると考えられている ${ }^{12}$. この肝芽腫で の CK 発現に関する検討では胆管紼胞としての CK 像 を発現することも報告され ${ }^{13)}$, 組織起源を考える上で 興味ある所見といえる.この様な未熟な肝上皮細胞が ヒト成人肝にも出現し，かつ肝癌発生にも関与するか 否かについては，極めて稀であるが成人肝にも間葉系 腫怚成分を伴う肝芽腫が発生することがあり ${ }^{14)}$ ，この 事実は成人肝にも多方向性分化能を有する未熟肝上皮 細胞が出現する可能性を示唆する現象といえる.

また, 一部の HCC 例, 特に低分化型 HCC で胆管細 胞の CK 発現を示す例があり ${ }^{15)}$, 最近, Hsia ら ${ }^{16)}$ は, $\mathrm{HBV}$ 関連性のヒト HCC 例の免疫組織化学的検討に おいて oval cell の特徵である胆管細胞の CK 像を呈 するとともにALB およびAFPの発現を示す細胞を 認めたことから HCC 発生過程への oval cell 類似細 胞の関与を推定している。さらに，HCCおよびCCC の両成分を有する混合型肝癌か胆管細胞の CK 像を発 現することから二方向性分化能を有する未熟肝上皮細 胞由来が推測されている ${ }^{17}$. また, SC 成分を伴う混合 型肝癌例も認められてお ${ }^{18,199}$, 多方向性分化能を有 する末熟肝上皮細胞由来を示唆する例とも考えられ る. 本 2 例の SC 成分の起源として HCC と SC 成分間 の移行像を認めたことより, HCC 成分の脱分化による 形質変化の結果とも考えられるが，両成分ともに胆管 細胞としてのCK を発現した点および前述したこれ までの二方向性ないしは多方向性分化能を有する未熟 肝上皮細胞の肝発癌過程への関与を示唆する実験的お 


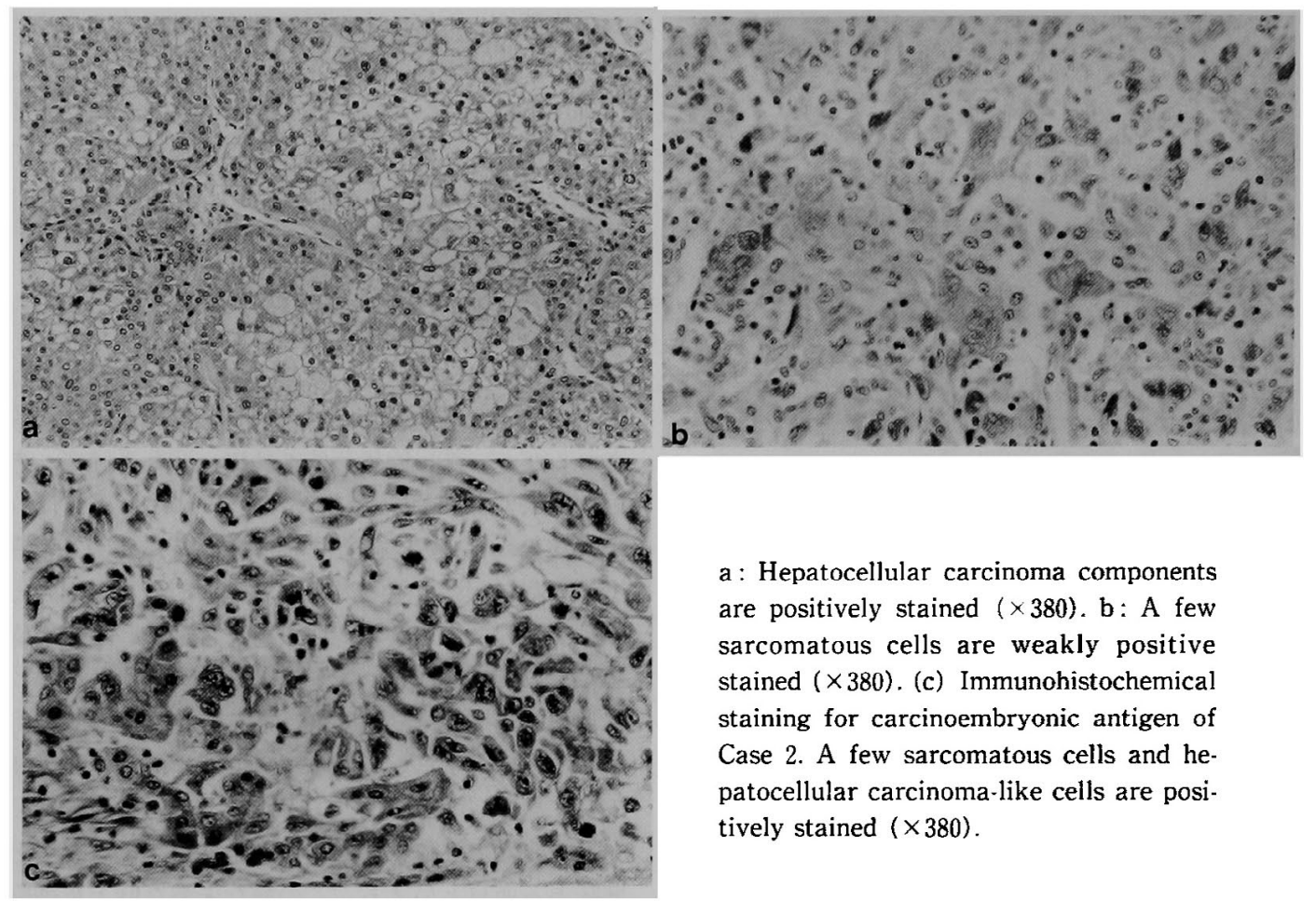

Fig. 7 (a,b) Immunohistochemical staining for $\alpha$-fetoprotein of Case 1 .

よび人体的研究例を考慮すれば，SC成分を伴う HCC が胆管細胞としてのCK を発現する多分化能を有する 未熟肝上皮細胞に由来する可能性も示唆され, $\mathrm{HCC} の$ 発生過程を考える上で本 2 例は興味ある症例と思われ た. 今後, 同様症例の集積による CK 発現像を中心と した病理組織発生学的検㢦を行うとともに多数の $\mathrm{HCC}$ 例の分化度別による CK 発現像との比較検討を 加えて行くことが望まれる.

\section{結 語}

$\mathrm{SC}$ 成分を伴う $\mathrm{HCC} の 2$ 剖検例を病理組織学的に 検索し,その組織起源について検討した。両例の SC 成 分は上皮成分に由来することが，さらに SC成分を伴 う HCC の発生母細胞として多方向性分化能を有する 末熟肝上皮細胞が関与する可能性が示唆された。

\section{女 献}

1）杉原茂孝, 柿添三郎, 伊藤裕司, 他：肉腫様変化を 示す肝細胞癌の臨床病理学的研究. 肝缄 $29: 71$ $-76,1988$

2) Kakizoe S, Kojiro M, Nakajima T: Hepatocellular carcinoma with sarcomatous change. Clinicopathologic and immunohistochemical studies of 14 autopsy cases. Cancer $59: 310-$ 316,1987

3) Kojiro M, Sugihara S, Kakizoe S, et al: Hepatocellular carcinoma with sarcomatous change: A special reference to the relationship with cancer therapy. Cancer Chemother Pharmacol 23 : S4-S8, 1989

4) Oda Y, Katsuda S, Nakanishi I: An autopsy case of hepatic sarcomatoid tumor: Immunohistochemical comparison with a sarcomatous component of hepatocellular carcinoma. Pathology International $44: 230-236,1994$

5) Moll R, Franke WW, Shiller DL, et al : Catalog of human cytokeratins : Patterns of expression in normal epithelia, tumors and cultured cells. Cell $31: 12-24,1982$

6) Sell S, Dunsford SA : Evidence for the stem cell origin of hepatocellularl carcinoma and cholangiocarcinoma. Am J Pathol 134 : 13471363, 1989

7) Lenzi R, Liu MH, Tarsetti F, et al: Histogenesis bile duct-like cells proliferating during 
ethionine hepatocarcinogenesis. Evidence for a biliary epithelial nature of oval cells. Lab Invest $66: 390-402,1992$

8) Steinberg P, Steinbrecher R, Radaeva S, et al : Oval cell lines OC/CDE6 and OC/CDE22 give rise to cholangiocellular and undifferentiated carcinomas after transformation. Lab Invest $71: 700-709,1994$

9) Tsao MS, Grisham IW: Hepatocarcinomas, cholangiocarcinomas, and hepatoblastomas produced by chemically transformed cultured rat liver epithelial cells. A light- and electronmicroscopic analysis. Am J Pathol 127 : 168181, 1987

10) Van Eyken P. Sciot R, Gallea F, et al: The development of intrahepatic bile ducts in man: A keratin-immunohistochemical study. Hepatology 8:1586-1595, 1988

11) Abenoza P, Manivel JC, Wick MR, et al: Hepatoblastoma: An immunohistochemical and ultrastructural study. Human Pathol 18 : $1025-1035,1987$

12）豊坂昭弘, 岡本英三：小昆肝癌の病理. 病理と臨床 $3: 380-388,1985$

13) Van Eyken P, Sciot R, Callea F, et al: A cytokeratin-immunohistochemical stdy of hepatoblastoma. Human Pathol 21: $302-308$. 1990

14) Altmann HW: Epithelial and mixed hepatoblastoma in the adult. Histological observations and general conditions. Path Res Pract $188: 16-26,1992$

15) Johnson DE, Herndier GB, Medeiros LJ, et al: The diagnostic utility of the keratin profiles of the hepatocellular carcinoma and cholangiocar. cinoma. Am J Surg Pathol 12: 187-197, 1988

16) Hsia CC, Evarts RP, Nakatsukasa H, et al: Occurrence of oval-type cells in hepatitis $B$ virus-associated human hepatocarcinogenesis. Hepatology $16: 1327-1333,1992$

17）村田哲也, 渡辺省三, 三浦 悟, 他 : 混合型肝細胞 癌·胆管細胞癌の 1 剖椮例. 肝裁 $29: 1649-1653$, 1988

18) Nakajima $T$, Kubosawa $H$, Kondo $Y$, et al: Combined hepatocellular-cholangiocarcinoma with variable sarcomatous transformation. Am J Clin Pathol $90: 309-312,1988$

19) Haratake J, Horie A: An immunohistochemical study of sarcomatoid liver carcinoma. Cancer $68: 93-97,1991$

\title{
Two autopsy cases of hepatocellular carcinoma with sarcomatous components
}

\author{
Keiji NaKasho*, Kei Yamaguchi, Tetsuo Yananoto, \\ Yoshiki AmURo and Kazuya HIGASIINo**
}

Through autopsies, we histopathologically investigated two cases of hepatocellular carcinoma (HCC) associated with a sarcomatous cell (SC) component, and included the results of immunohistochemical staining using various phenotypic markers. A transitional from the HCC component to the SC component was observed in both cases. Mallory bodies were present in both components in Case 1. Immunohistologically, $\alpha$-fetoprotein was expressed in both components in Case 1 while carcinoembryonic antigen was expressed in both components in Case 2. The tumor components in both cases displayed the cytokeratin patterns of bile duct cells. On the basis of these findings, we reported on the histological origin of $\mathrm{HCC}$ associated with a SC component, and added a discussion based on the literature.

\footnotetext{
* The Second Department of Pathology, Hyogo College of Medicine (Nishinomiya)

** The Third Department of Internal Medicine, Hyogo College of Medicine (Nishinomiya)
} 